\title{
Stractural Behavior of Reinforced Concrete Corbel Using High- Strength Materials under Monotonic and Repeated Loads
}

\author{
Prof. Dr. Al-Talqany F. J. ${ }^{1} \&$ Alhussainy A. M. ${ }^{1}$ \\ ${ }^{1}$ Structural, Engineering, Kufa, Iraq \\ Correspondence: Ali Malik Alhussainy, Structures, Al-Kufa University, City ZIP/Post code, Iraq. Tel: 964-7706- \\ 020-791. E-mail: alim.alhussainy@uokufa.edu.iq
}

Received: March 29, 2019; Accepted: April 9, 2019; Published: April 17, 2019

\begin{abstract}
The growth of Development techniques for high strength materials and precast structures leads to increase the interesting on these technics. This study will focus on the corbels which made from high strength materials (Reactive Powder Concrete materials) which including the testing of (15 samples) and their cost, twelve of them were testing under a vertical monotonic load, while the other sample putted under the effect of repeated load. As well as, the samples divided to various groups according to many variable parameters which are (ratio of steel fiber, (a/d) ratio, existing the secondary stirrups steel, type of loading). Thus, these parameters effected on the ultimate shear strength, first crack loading, ultimate deflection, load-deflection curves, ductility and stiffness.
\end{abstract}

Keywords: Corbel, Reactive Powder, Steel Fiber, Repeated Load

\section{Introduction}

The precast structures have an important role during reconstruction in all projects, because it is being characterized as: performance quickly and the requirements of executed are easy and available. Corbels structures are useful due their function in the construction field. Also they should be made from high strength materials because the strength precast structure coming from the strength of the members, (Kriz and Raths, 1965).

In general corbels are a level projected and the ratio of shear arm to the depth must be less than 1.0 to called corbels and ACI requirements cover it else called cantilever. On the other hand Corbels are used in a wide ranges especially in High-rises building, bridges ....etc.

Where Corbels after loading to up failure, it can be seen a flexible failure mode in both (tension and compression), also may fail as diagonal splitting or shear failure due to horizontal forces (Wight, 2001).

Many researches were tackled the corbel structure are interesting on the behavior of corbel and ways of strengthening also uses different kind from concrete (NC, SCC, SC, HSC, LWC etc.).

Yassin 2016, studied the effect of employing composite materials for strengthening RC Corbels, the material that used is woven carbon fiber fabrics. Where the research aim was to find the effectiveness of using carbon fiber fabric materials for increasing the capacity of carrying load for corbels that subjected to unreversed repeated loading systems. The experimental work was done by casting twenty specimens of normal-weight reinforced concrete corbels, some of these corbels were externally strengthened with carbon fiber fabric strips. The corbels were divided into two groups according to the type of loading. The results of the experimental and analytical parts have indicated that the external strengthening with carbon fiber fabric strips have strengthen the ability of corbels. And the improvement in corbels resistance ability was $11 \%, 15 \%$ and $27 \%$ for the horizontal, inclined and mixed configurations respectively under static load. While for the unreversed repeated loaded corbels, the improvement in corbels resistance ability was about $11 \%, 18 \%$ and $21 \%$ for the horizontal, inclined and mixed configurations respectively.

Farhan 2014, examined twenty four, vibrated self-compacting, normal and high strength, corbels tested under vertical loading. Half from these samples were tested under monotonic (static) loading until failure, while the other twelve corbels were checked by repeated loading in order to show the attitude of samples under variables load levels $(60 \%, 80 \%$ and $90 \%)$ of the peak load from reference load of corbels in addition to the considerations variables which adopted: The conclusions showed that the samples of corbels are always increasing in the deflections value during successive periods, and failed in a rather more ductile pattern as compared with corbels 
subjected to monotonic loading system, the reduction ratio was from $(1.7 \%$ to $13.7 \%)$ depending on the level of repeated load and the others parameters.

Al-Haddad 2016, tested twenty-two reinforced hybrid and homogenous concrete corbel-column systems under the effect of single (unsymmetrical) vertical load. Twenty two samples were classified into five groups to study the influences of parameters which is: kind of hybrid concrete, ratio of a/d, area and type of hybridization in corbel column connect region (both of using HSC and SFR concrete), the existing of vertical construction joint at the interface of corbel-column. The results which it obtained from the experimental testing showed that changing corbel concrete type leads to increased ultimate strength as $26 \%, 38 \%$ for high strength and steel fiber reinforced concrete. In both cases, shear capacity increased with a range between $10 \%-41 \%$ for specimens hybridized monolithically with HSC layers, while it increased with a range between $19 \%$ - $44 \%$ for specimens hybridized monolithically with SFRC layers; compared with homogenous NSC systems having same (a/d) ratio.

As for the repeated load, most researchers do not take the effect of repeated load and now becoming important to check the portability of structure to absorption of loads. The significant of high strength material in precast structures (such as RPC) and effect of repeated load, this research was adopted.

\section{Test Program}

\subsection{Sample Details}

All samples have the same shape and dimensions and reinforcement. And the dimensions of corbel included $(150 * 150 * 450) \mathrm{mm}$ for column and two cantilever on sides of column $(200 * 150 * 150) \mathrm{mm}$ for each corbel, as for the reinforcement, column have (4Ø16mm) and $(5 \varnothing 10 \mathrm{~mm} @ 80 \mathrm{~mm})$ for stirrups, while corbel have (2Ø12 $\mathrm{mm})$ for main reinforcement and (Ø $10 \mathrm{~mm}$ ) for some corbels which it have stirrups, as shown in Figure 1.

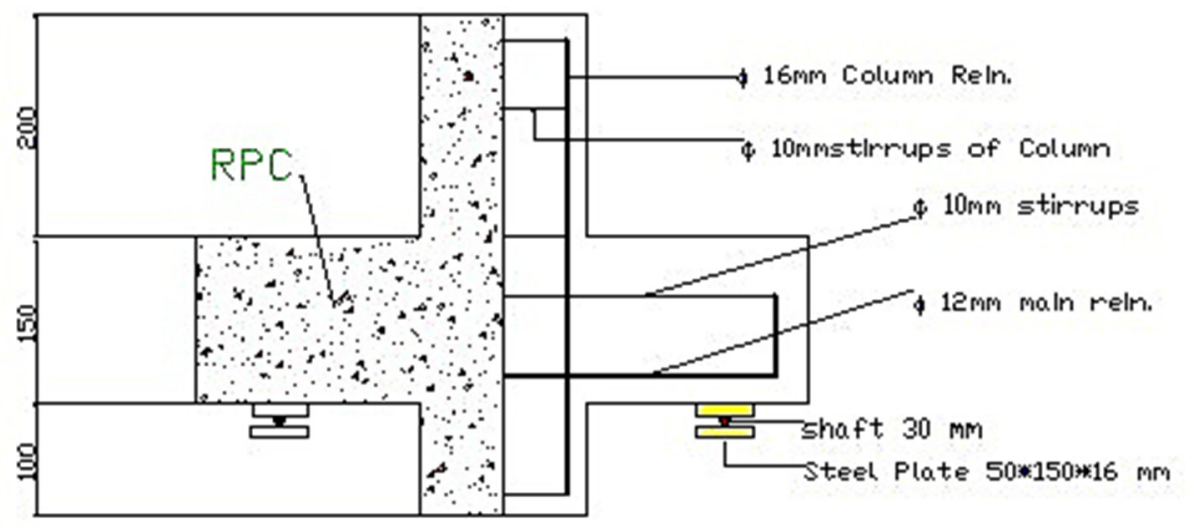

Figure 1. Corbel Details

\subsection{Materials Properties and Curing}

The RPC is consisting from materials which they are: steel fiber, silica fume, cement, sand, and superplastizer, in this research the following ratio was used for each RPC material:

$\begin{array}{ll}\text { Cement } & 1000 \mathrm{KG} / \mathrm{m}^{3} \\ \text { Sand } & 1000 \mathrm{KG} / \mathrm{m}^{3} \\ \text { Steel fiber } & \text { Three variant ratio which is }(0,1 \& 2) \% \\ \text { Silica fume } & 15 \% \\ \text { HWRWA } & 1.9 \% \text { type (sika viscocrete } 5930) \\ \text { W/C } & 0.17\end{array}$

The type of curing for RPC is important and effected on the compressive strength of concrete especially in early ages. The way of curing which specified by (Tam) (impressed the samples in water $@ 60 \mathrm{C}^{\circ}$ for during six days) as shown in figure (2). And the average of compressive strength results was recorded as shown in table 1. 

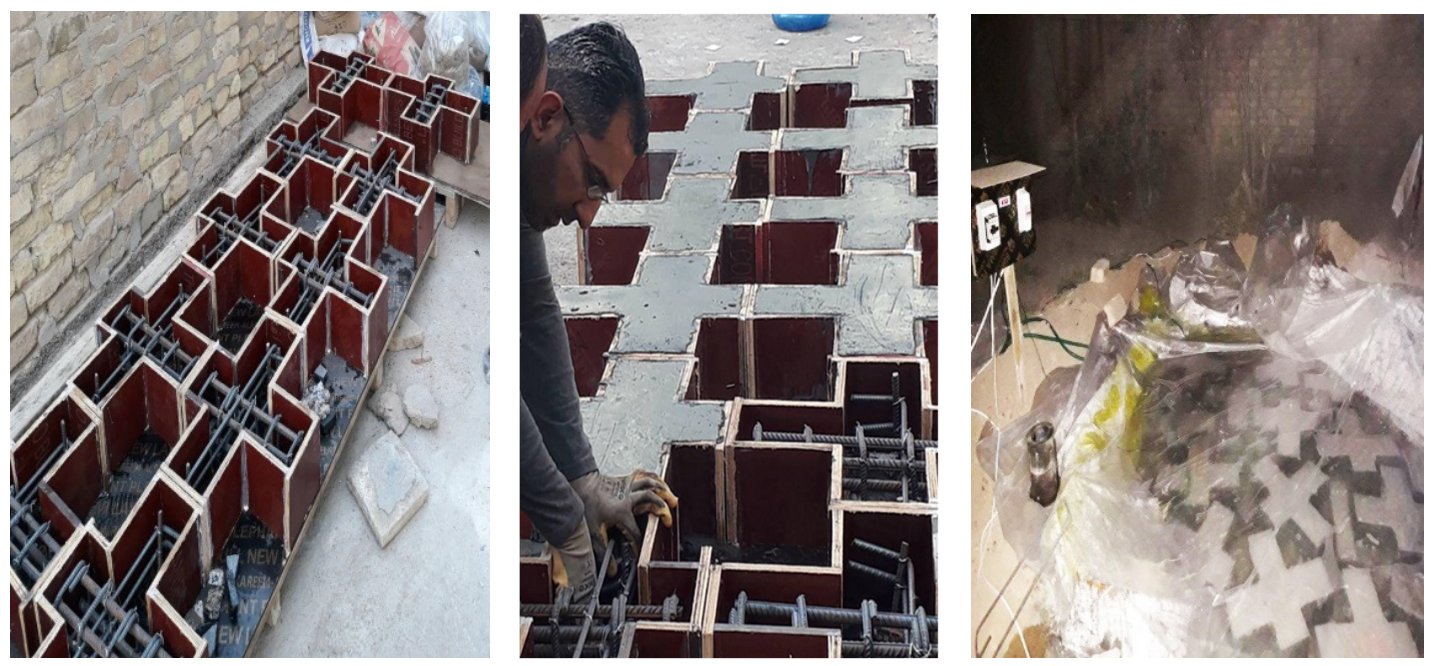

Figure 2. Casting Stages

\subsection{Samples Description}

According to the variable parameters, samples were classified for many groups. So the table 1 shows the samples with their parameters.

Table 1. Description of samples and compressive strength

\begin{tabular}{lllllllll}
\hline \multirow{2}{*}{ No. } & \multirow{2}{*}{$\% \mathrm{~S} . \mathrm{F}$} & $\mathrm{a} / \mathrm{d}$ & \multirow{2}{*}{ Stirrups } & Loading & $\mathrm{fc}^{\prime}$ & \multicolumn{3}{l}{ Fcu } \\
\cline { 7 - 9 } & & & & & & & \\
C1 D & 0 & 0.5 & without & Static & & & & \\
C2 & 0 & 0.75 & with & Static & & & & \\
C3 & 0 & 0.75 & without & Static & 71.36 & 80.52 & 80.28 & 89.23 \\
C4 & 0 & 1 & without & Static & & & & \\
C5 & 0 & 1 & without & Repeated & & & & \\
\hline C6 & 1 & 0.5 & without & Static & & & & \\
C7 & 1 & 0.75 & with & Static & & & & \\
C8 & 1 & 0.75 & without & Static & 92.102 & 110.64 & 95.20 & 112.62 \\
C9 & 1 & 1 & without & Static & & & & \\
C15 & 1 & 1 & without & Repeated & & & & \\
\hline C10 & 2 & 0.5 & without & Static & & & & \\
C11 & 2 & 0.75 & with & Static & & & & \\
C12 & 2 & 0.75 & without & Static & 98.79 & 130.01 & 124.32 & 131.32 \\
C13 & 2 & 1 & without & Static & & & & \\
C14 & 2 & 1 & without & Repeated & & & & \\
\hline
\end{tabular}

\subsection{Testing Procedure}

The testing process was divided into two methods monotonic and repeated, The monotonic method investigate by loading $(10 \mathrm{kN})$ in each time and recording deflection by a dial gage with an accuracy 0.01 , as well as the cracks and cracks width were recorded every $(50 \mathrm{kN})$. The loading procedure continues up to the failure.

While the regime of repeated loading was by applying the compression load on the samples and as a static load, the deflection was recorded for each $(10 \mathrm{kN})$ and the cracks for each $(50 \mathrm{kN})$,and when loading reach to $0.25 \mathrm{Pu}$ $(\mathrm{Pu}$ is for the reference, that obtained from the samples have the same parameters under static load), after that unloading to the zero load and recorded the deflection for each $10 \mathrm{kN}$, This process repeated (5 times), then to $0.75 \mathrm{Pu}$, finally, the sample was undergone load from zero to failure.

All steps of this procedure (for both static and repeated loads) were applied on the samples at University of Kufa, Faculty of Engineering. 


\section{Results and Discussion}

The results which obtain from experimental works mentioned in table 2, the results were including the first cracking load, ultimate load, ultimate deflection and failure mode.

\subsection{Load-Deflections Behavior}

The behavior of the deflection curve with increasing load was depending on the parameters, where each parameter has an effect on the corbel in a different way due to the difference of material properties and loading condition, (Ihssan, 1993), so the attitude of load-deflection curve was as following:

\subsubsection{Effect of Steel Fiber}

The curves shown in figures $3,4,5 \& 6$, reveal that increasing steel fiber leads to decreased deflection.

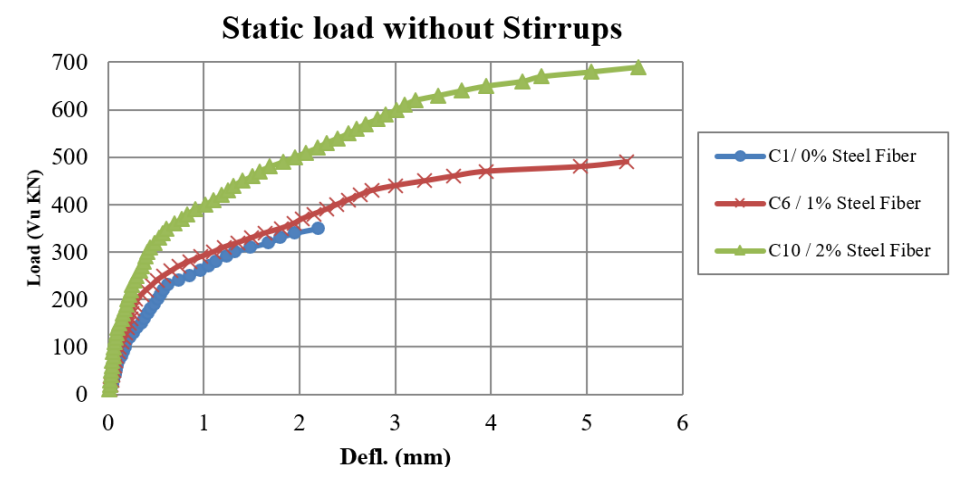

Figure 3. Load-deflection curves for Samples (C1, C6 \&C10) with $(\mathrm{a} / \mathrm{d}=0.5)$

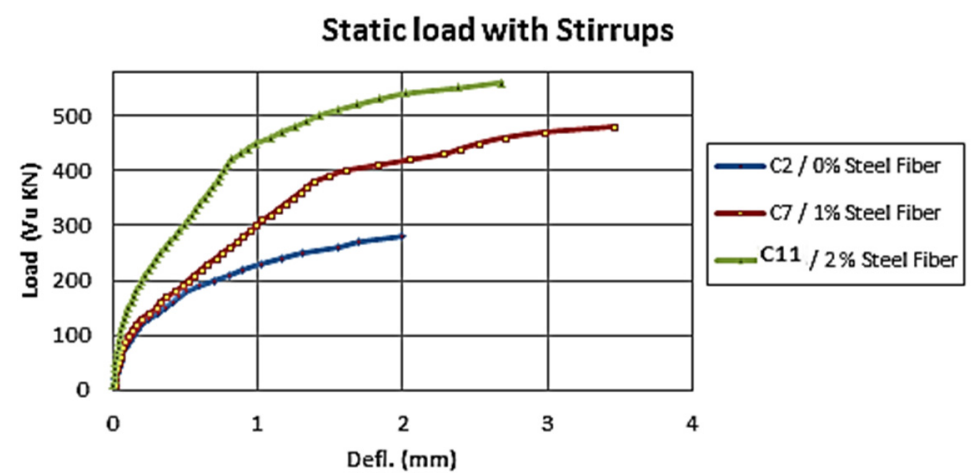

Figure 4. Load-deflection curves for Samples (C2, C7 \&C11) with $(\mathrm{a} / \mathrm{d}=0.75)$

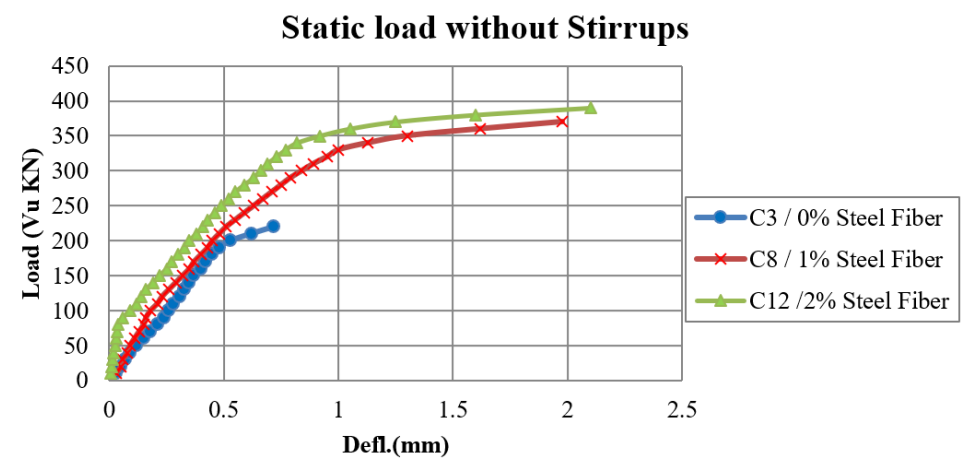

Figure 5. Load-deflection curves for Samples (C3, C8 \&C12) with $(\mathrm{a} / \mathrm{d}=0.75)$ 


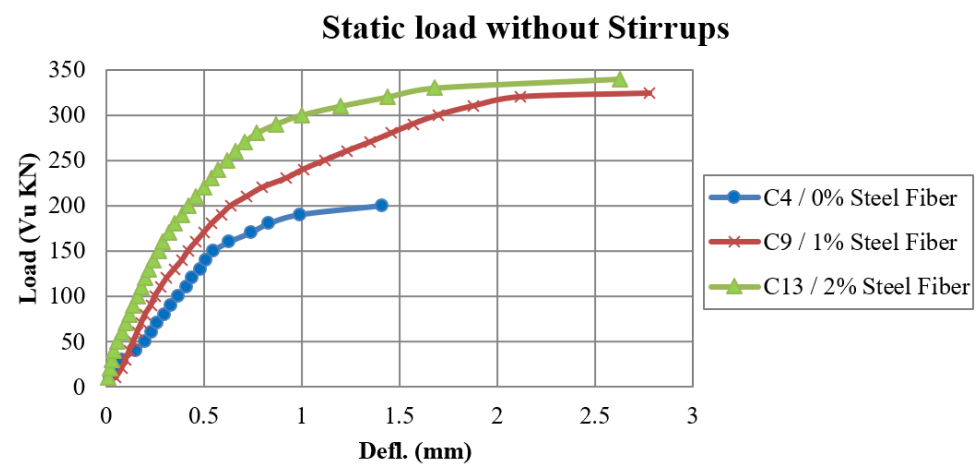

Figure 6. Load-deflection curves for Samples (C4, C9 \&C13) with $(\mathrm{a} / \mathrm{d}=1)$

\subsubsection{Effect of (a/d) Ratio}

Three groups with reference to amount of steel fiber represent the effect of $(\mathrm{a} / \mathrm{d})$, the noted through the curves, the increasing $(\mathrm{a} / \mathrm{d})$ leads to increasing deflection with constant steel fiber rate as shown in Figure 7, 8 \& 9 .

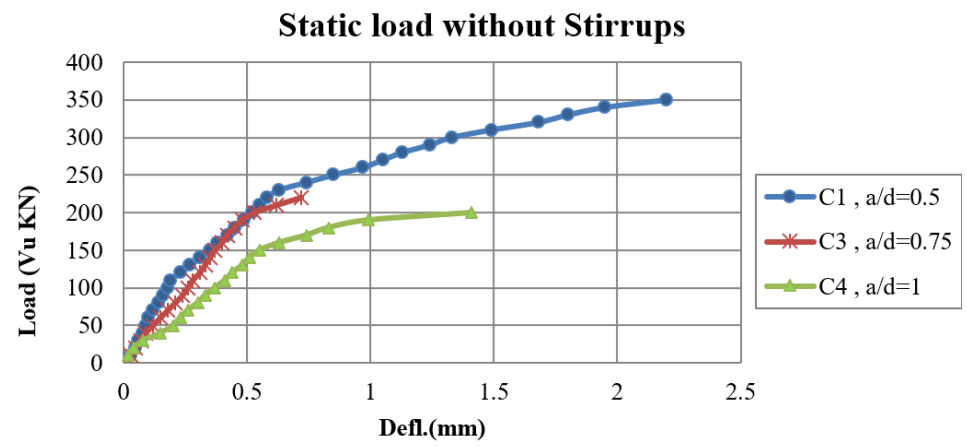

Figure 7. Load-deflection curves for sampling $\mathrm{C} 1, \mathrm{C} 3$ \&C4 with (S.F=0\%)

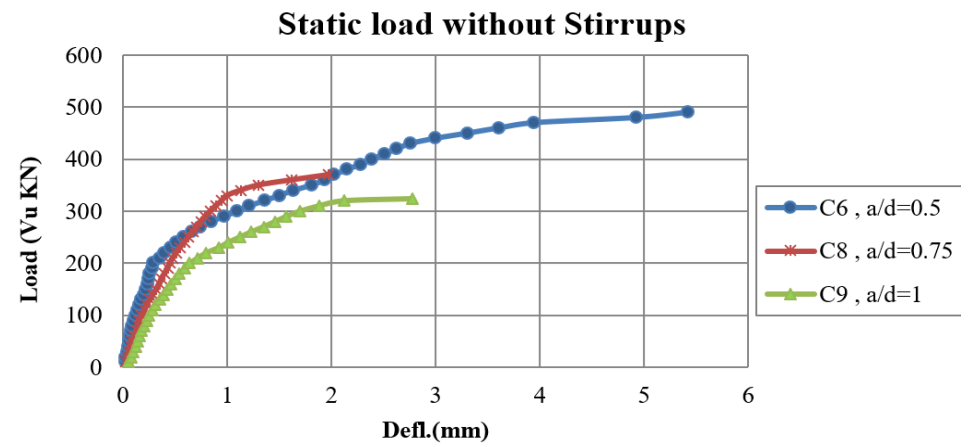

Figure 8. Load-deflection curves for sampling C6, C8 \&C9 with (S.F=1\%)

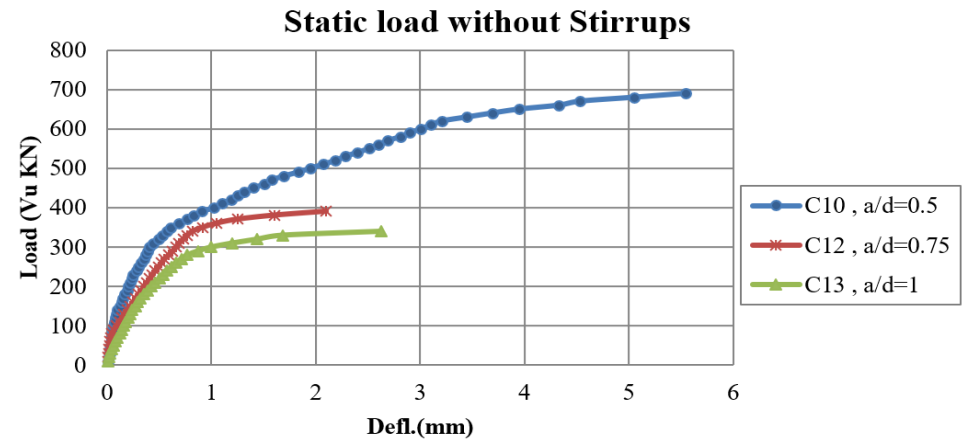

Figure 9. Load-deflection curves for sampling C10, C12 \&C13 with (S.F=2\%) 


\subsubsection{Effect of Stirrups}

The appearance of steel stirrups influence on the deflection slightly, where the normal samples without stirrups have a larger deflection than samples with stirrups, as shown in Figure 10, $11 \& 12$.

\section{Static load with S.F $0 \%$}

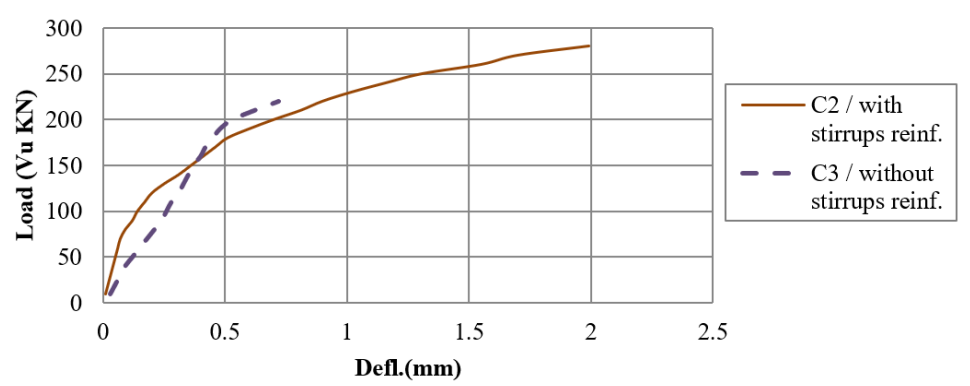

Figure 10. Effect of stirrups reinforced on the load-deflection curve for sample with $(\mathrm{a} / \mathrm{b}=0.75)$

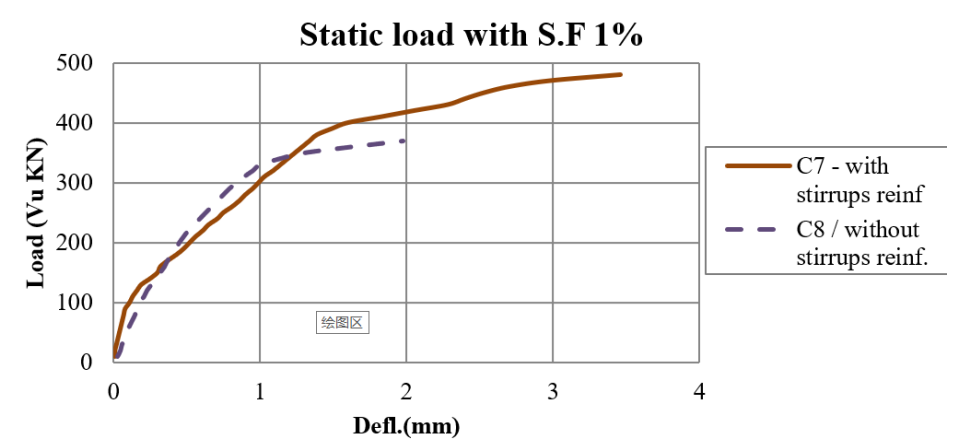

Figure 11. Effect of stirrups reinforced on the load-deflection for sample with $(\mathrm{a} / \mathrm{b}=0.75)$

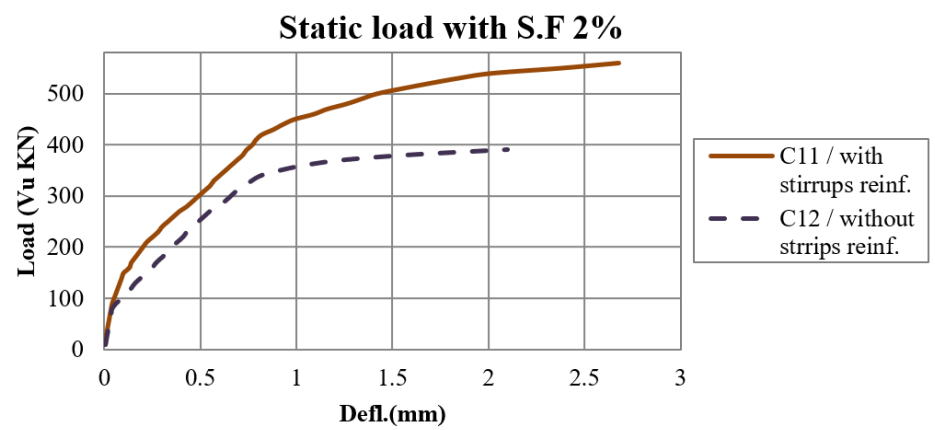

Figure 12. Effect of stirrups reinforced on the load-deflection curve for sample with $(a / b=0.75)$

\subsubsection{Effect of Repeated Load}

Under repeated load the curves of load with deflection were similar in the first stage then differ with increased load depending on steel fiber ratio. The final loading of load deflection curve was repeated as shown in Figure 13, $14 \& 15$.

\section{Repeated load without Stirrups}

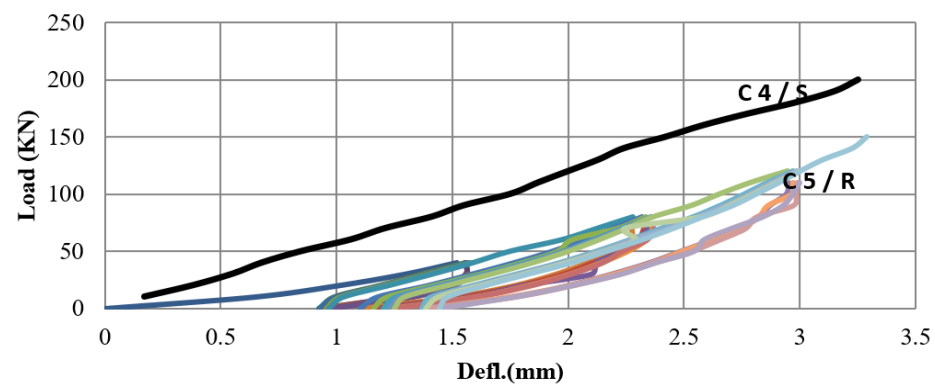

Figure 13. Effect of repeated load on samples with S.F $=0 \%$ and $(\mathrm{a} / \mathrm{b}=1)$ 


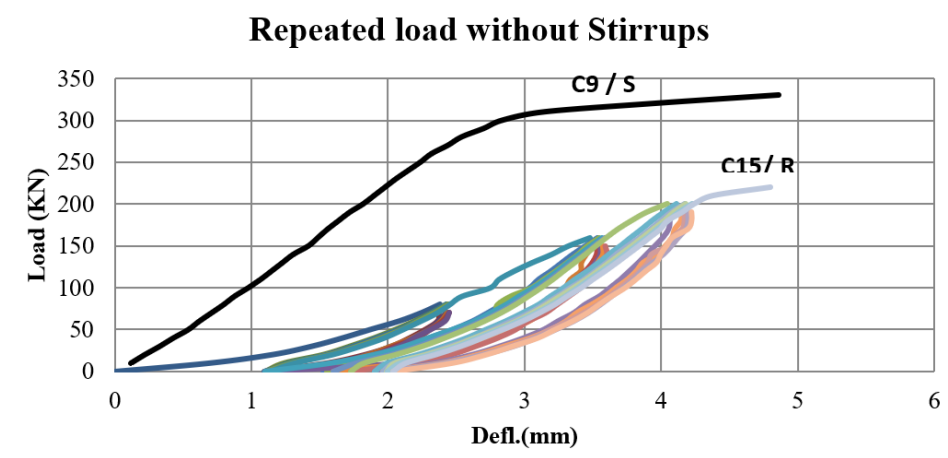

Figure 14. Effect of repeated load on samples with $\mathrm{S} . \mathrm{F}=1 \%$ and $(\mathrm{a} / \mathrm{b}=1)$

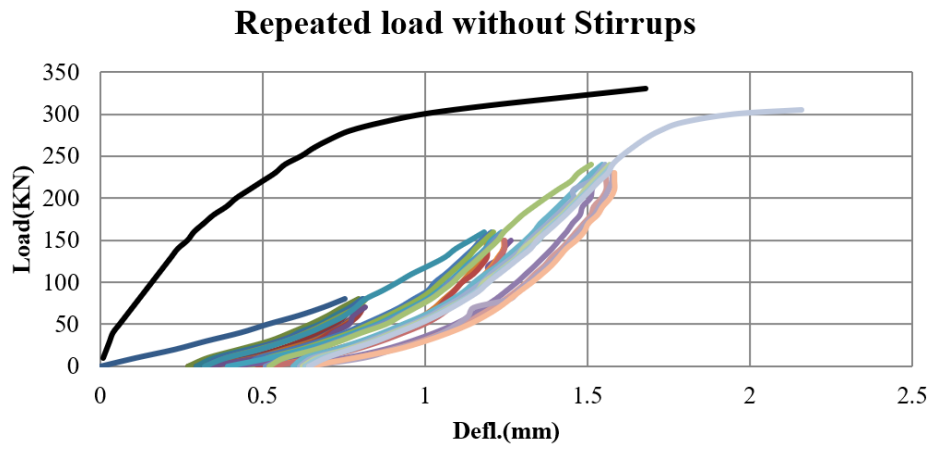

Figure 15. Effect of repeated load on samples with S.F $=2 \%$ and $(\mathrm{a} / \mathrm{b}=1)$

\subsection{First Crack and Ultimate Loads}

The first crack and the ultimate shear strength were important in design requirements, (Zielinski and Riogotti, 1995), and from the results it can be seen that the increase steel fiber delayed the occurrence of first cracks with ratio (19.2\%- 40\%) and increase ultimate load about (43\% -97.1\%) also appearing of secondary reinforcement that increase the ultimate load about (126-144) \% but its effect is limited on the first crack.

While the ratios of $(\mathrm{a} / \mathrm{d})$ leads to increase the ultimate load by ratio $(16.75-105.70) \%$ with decreasing the $(\mathrm{a} / \mathrm{d})$ ratio, and accelerate the appearance of the first crack approximately $(89.63-177.81) \%$.

Also, the influence of repeated loading was high for ultimate load where it leads to decreases the ultimate load about (12-26)\% and it has no effect on the first crack appearing the table (2) shows the values of results for both first cracking and the ultimate load for each sample.

Table 2. Values of ultimate load and first crack

\begin{tabular}{lll}
\hline No. & F.C & U.L \\
\hline C1 & 110 & 350 \\
C2 & 75 & 280 \\
C3 & 50 & 220 \\
C4 & 40 & 200 \\
C5 & 40 & 159 \\
C6 & 200 & 490 \\
C7 & 90 & 480 \\
C8 & 98 & 380 \\
C9 & 80 & 324 \\
C10 & 300 & 690 \\
C11 & 150 & 560 \\
C12 & 150 & 390 \\
C13 & 125 & 340 \\
C14 & 110 & 305 \\
C15 & 70 & 287 \\
\hline
\end{tabular}




\subsection{Ductility and Stiffness}

The increase of high strength for concrete makes it a brittle materials and the addition steel fiber will increase the ductility, (Ali \& White, 2001), and also increase stiffness as shown in the table 3.

Table 3. The ratios of ductility and stiffness.

\begin{tabular}{llllllllll}
\hline No & Steel fiber & $\mathbf{a} / \mathbf{d}$ & Stirrups & loading & $\Delta \mathbf{c r}$ & $\Delta \mathbf{y}$ & $\Delta \mathbf{u}$ & Ductility & Stiffness \\
\hline 1 & 0 & 0.5 & without & static & 0.19 & 1.09 & 2.20 & 2.01 & 578.95 \\
2 & 0 & 0.75 & with & static & 0.08 & 1.10 & 1.99 & 1.81 & 937.50 \\
3 & 0 & 0.75 & without & static & 0.12 & 0.42 & 0.72 & 1.71 & 416.67 \\
4 & 0 & 1 & $=$ & static & 0.15 & 0.87 & 1.41 & 1.63 & 266.67 \\
5 & 0 & 1 & $=$ & repeated & 0.63 & 1.54 & 1.59 & 1.03 & 63.50 \\
6 & 1 & 0.5 & $=$ & static & 0.29 & 2.53 & 5.42 & 2.14 & 689.66 \\
7 & 1 & 0.75 & with & static & 0.08 & 1.64 & 3.46 & 2.11 & 1125.00 \\
8 & 1 & 0.75 & without & static & 0.18 & 1.00 & 1.98 & 1.98 & 544.44 \\
9 & 1 & 1 & $=$ & static & 0.20 & 1.43 & 2.78 & 1.94 & 400.00 \\
15 & 1 & 1 & $=$ & repeated & 0.94 & 2.69 & 2.80 & 1.04 & 74.47 \\
10 & 2 & 0.5 & $=$ & static & 0.41 & 1.81 & 5.54 & 3.06 & 731.71 \\
11 & 2 & 0.75 & with & static & 0.10 & 1.07 & 2.68 & 2.50 & 1500.00 \\
12 & 2 & 0.75 & $=$ & static & 0.22 & 0.89 & 2.10 & 2.36 & 681.82 \\
13 & 2 & 1 & $=$ & static & 0.21 & 1.33 & 2.63 & 1.98 & 595.24 \\
14 & 2 & 1 & $=$ & repeated & 1.11 & 1.88 & 2.16 & 1.15 & 99.10 \\
\hline
\end{tabular}

\section{Conclusion}

From the results obtained, it is possible identify the following as:

1. Adding steel fiber improved the strength of corbel (43-97.1)\% for ratio (1 and 2)\% S.F. and delay the appearing of first crack (19.2-40)\%, as well as decreasing the ultimate deflection (100-114)\% with improving the ductility (3.32-7.62)\% and stiffness (8-25)\% for (1 and 2)\% S.F respectively.

2. Increasing shear arm to depth ratio has a significant effect on the ultimate capacity where decreased it about $(16.75-105.7) \%$, while first crack observed higher for $(\mathrm{a} / \mathrm{d}=0.5)$ than the other ratio and about (89.63-177.81) \% depending on the rate of $(\mathrm{a} / \mathrm{d})$. Ductility increase when $(\mathrm{a} / \mathrm{d})$ increased about (11.62$122.42) \%$ reverse the stiffness where decreased (-52.62-758.72) \%.

3. The appearance of shear stirrups progressed the ultimate load about (126-144) \% with limited effect on the first crack and ultimate deflection, in general samples with stirrups were lower than samples without stirrups. Ductility ratio were minimal without stirrups reinforced compared with samples contained stirrups and about (6-7) \% but stiffness changed a lot and about (107-125) \%

4. The effect of change way of loading had a negative impact where leads to reduce the ultimate capacity with ratio $(26,13,12) \%$ for $(0,1,2) \%$ steel fiber , while ductility decreased $(58,86$ and 72$) \%$ and stiffness decreased ( 420,537 and 601)\%.

\section{References}

ACI-Committee 318, Building Code Requirements for Structural Concrete. ACI-318M-14.and.commentaryACI318M-14, American Concrete Institute.

Al-Haddad, W. H. (2010). Experimental and Theoretical Investigation for Behavior of Hybrid Reinforced Concrete Corbel-Column Connection", Ph.D. Thesis, University of Babylon, Iraq.

Ali, M. A., \& White, R. N. (2001). Consideration of compression stress bulging and strut degradation in truss modeling of ductile and brittle corbels. Engineering Structures, 23(3), 240-249. https://doi.org/10.1016/S0141-0296(00)00040-7

Al-Nasrawi, A. M. (2015). Analysis for behavior \& ultimate strength of concrete corbels with hybrid reinforcement. M.Sc. Thesis, University of Babylon.

Farhan, R. S. (2014). Behavior of Reinforced Concrete Corbels under repeated lodging. Ph.D. Thesis, AL-Nahreen University, Iraq, p.10. 
Ihssan, M. A. (1993). Reinforced Concrete Beams with Steel Fibers Subjected to Static Cyclic Loads. M.Sc., University of Technology, Baghdad, Iraq.

Ihssan, M. A. (1993). Reinforced Concrete Beams with Steel Fibers Subjected to Static Cyclic Loads ", M.Sc., University of Technology, Baghdad.

Kriz, L. B., \& Raths, C. H. (1965). Connections in Precast Concrete Structures: Strength of Corbels. PCI Journal, 10(1), Feb., 1965. https://doi.org/10.15554/pcij.02011965.16.61

Rodham, M. M. S., Al-Shafi'i, N. T. H., \& Hasan, M. M. (2017). Ultra-high performance steel fibers concrete corbels: experimental investigation. Case Studies in Construction Materials.

Tam, C. M., Tam, V. W. Y., \& NG. K. M. (2010). Optimal conditions for producing reactive powder concrete. Magazine of Concrete Research, 62(10), October, 701-716. https://doi.org/10.1680/macr.2010.62.10.701

Wight, J. K. (2001). Use of Strut and Tie Modeling within the ACI Building Code. In Structures 2001: A Structural Engineering Odyssey, 140, pp.1-2. https://doi.org/10.1061/40558(2001)140

Yassin L. A. G. (2016). Behavior of RC Corbels Strengthened With CFRP Under Monotonic And Repeated Loading. Ph.D. Thesis, University of Technology, Iraq.

Zielinski, Z., \& Riogotti M. (1995). Test on Shear Capacity of Reinforced Concrete. Journal of Structural Engineering, November.

Zielinski, Z., \& Riogotti, M. (1995). Test on Shear Capacity of Reinforced Concrete. Journal of Structural Engineering, November 1995. https://doi.org/10.1061/(ASCE)0733-9445(1995)121:11(1660)

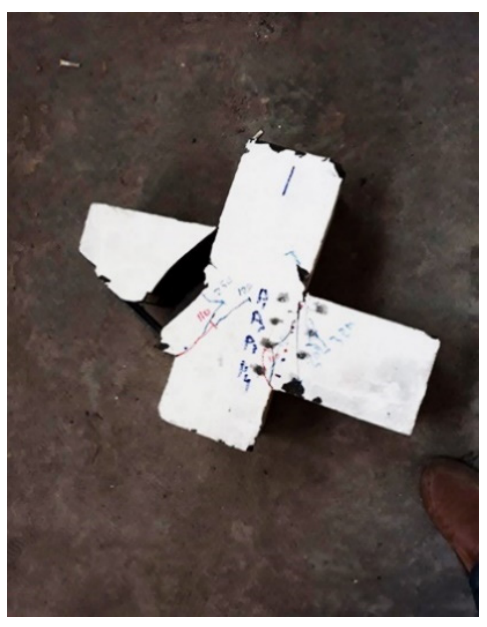

(a)

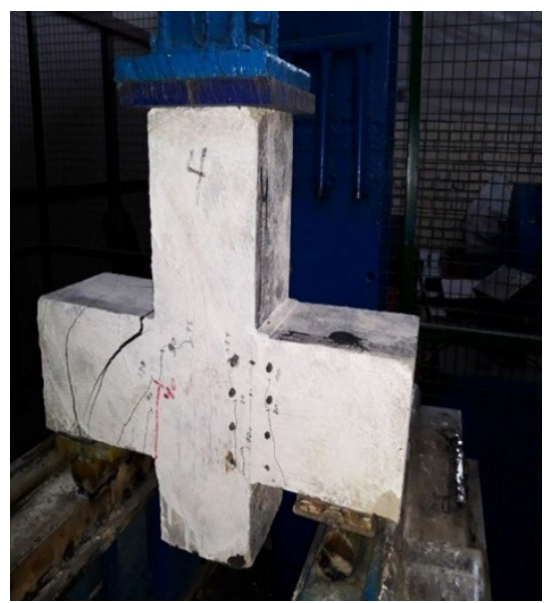

(d)

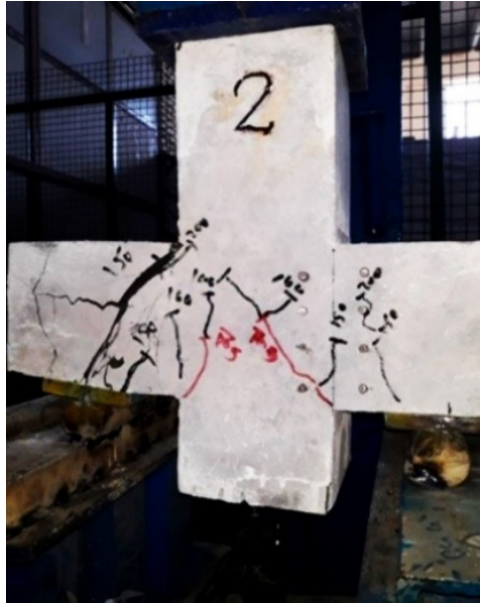

(b)

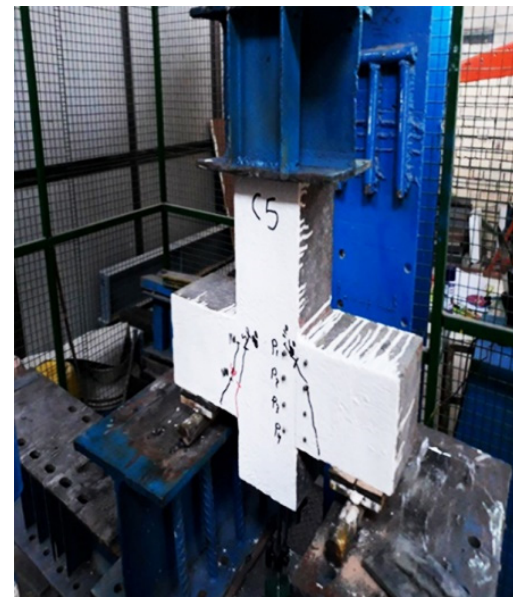

(e)

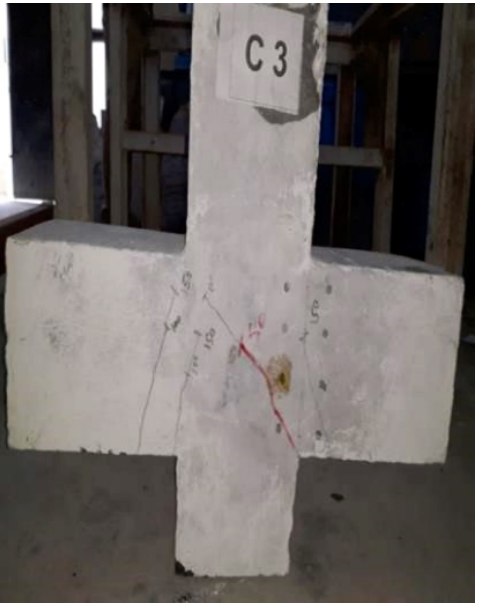

(c)

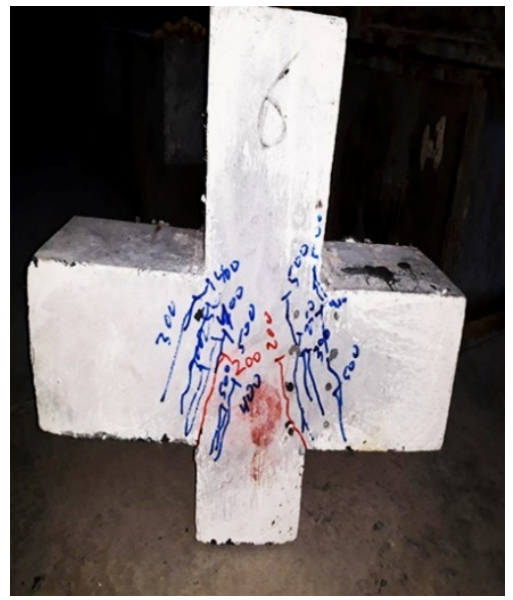

(f) 


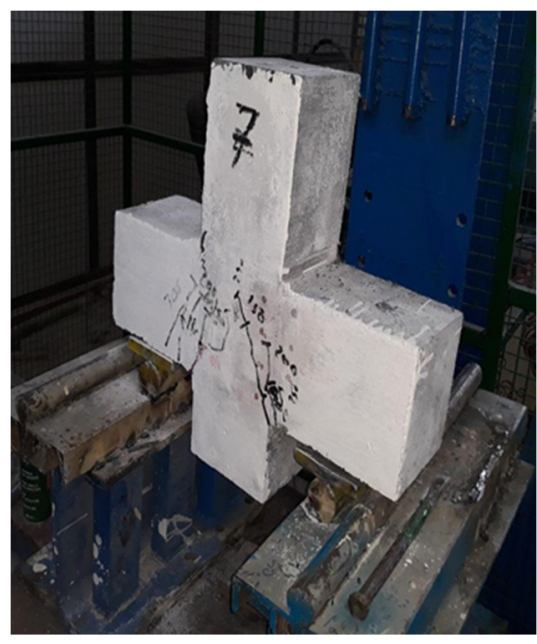

(g)

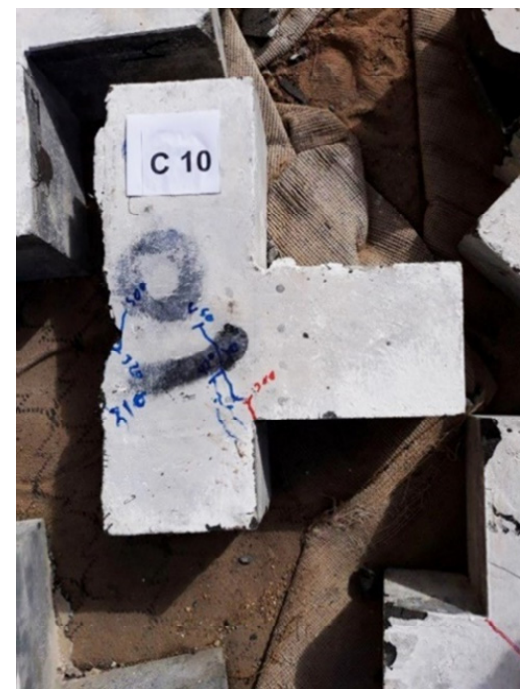

(1)

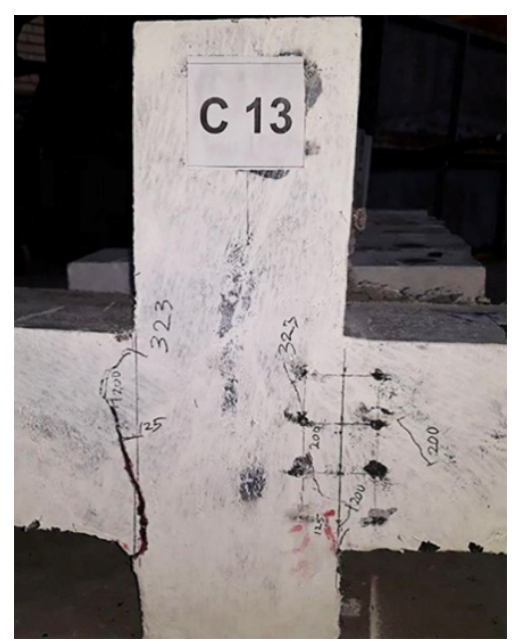

(o)

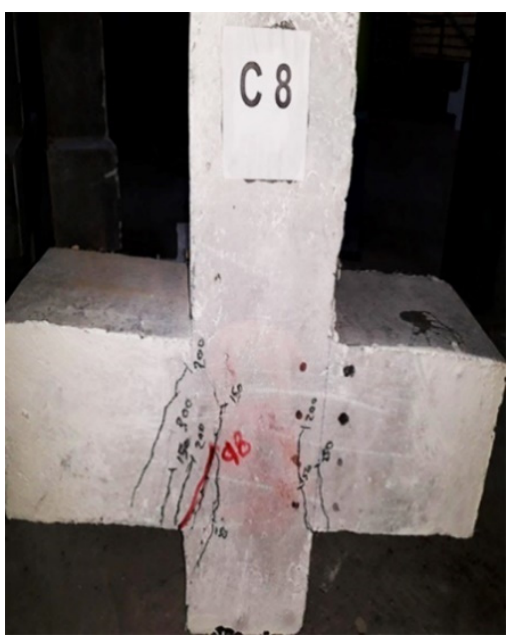

(h)

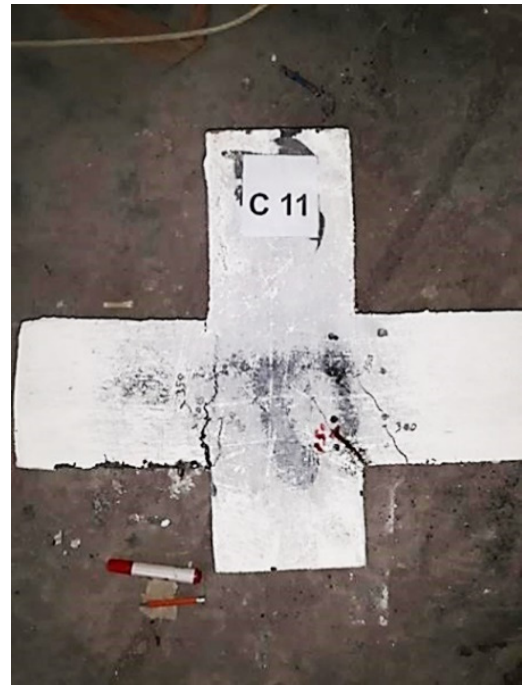

(m)

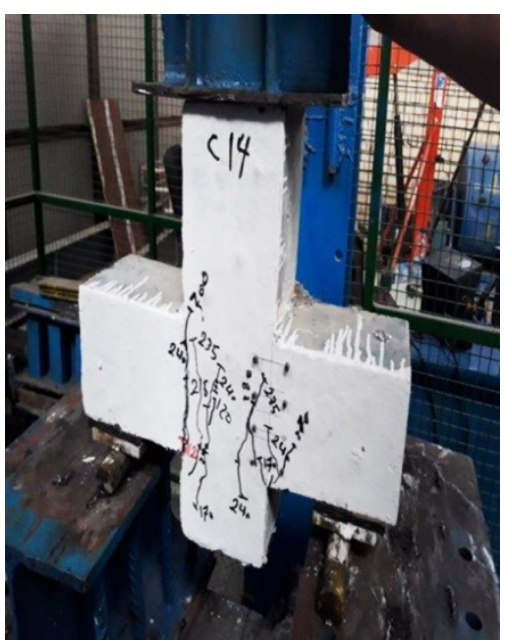

(p)

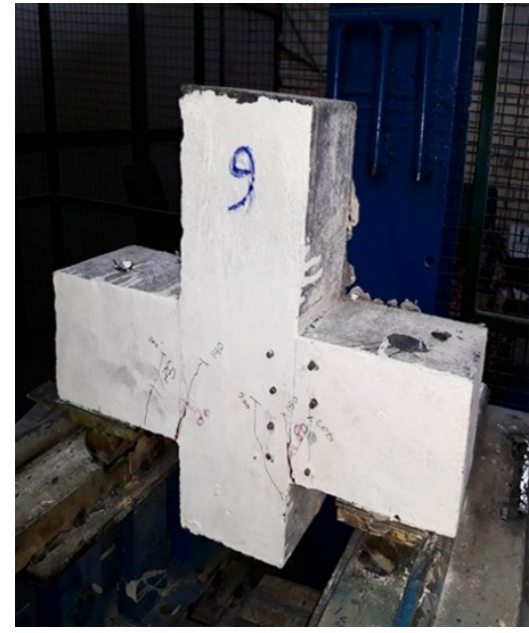

(k)

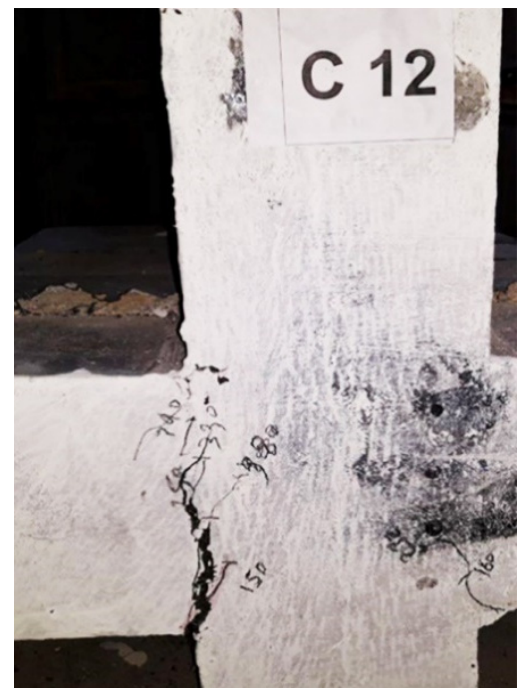

(n)

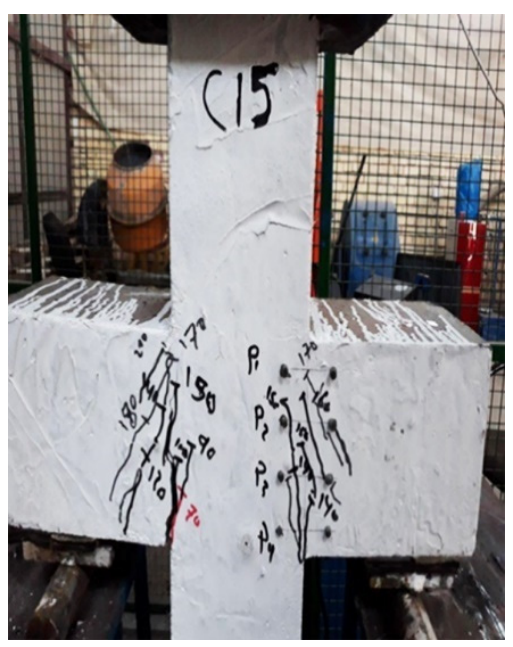

(q)

Figure 16. Samples of Corbel after loading 


\section{Copyrights}

Copyright for this article is retained by the author(s), with first publication rights granted to the journal.

This is an open-access article distributed under the terms and conditions of the Creative Commons Attribution license (http://creativecommons.org/licenses/by/4.0/). 